\title{
Nonlinear Control Design for Maximum Power Point Tracking and Unity Power Factor of a Grid-Connected Photovoltaic Renewable EnergySystems
}

\author{
M. Guisser ${ }^{1 *}$, M. Aboulfatah ${ }^{1}$, E. Abdelmounim ${ }^{1}, H$. Medromi $^{2},{ }^{2}$. Saadi ${ }^{2}$ \\ ${ }^{1 *}$ (Department of Electrical Engineering, CRMEF-Settat.ASTI Laboratory, FST-Settat, University Hassan I, \\ Morocco) \\ ${ }^{I}$ (ASTI Laboratory, FST-Settat, University Hassan I, Morocco) \\ ${ }_{2}^{2}$ (LISER Laboratory, ENSEM-Casa, University Hassan II Ain-Chok, Morocco)
}

\begin{abstract}
This paper deals with the design of a nonlinear controller for single-phase grid-connected photovoltaic $(P V)$ renewable energy systems to maintain the current injected into the grid in phase with grid voltage and to regulate the DC link voltage and to extract maximum power point tracking (MPPT).The system configurationincludes a photovoltaic generator, DC-DCconverter, DC-AC inverter coupled to grid network. The controller is designed using thebackstepping control to optimize the PV energy extraction and to achieve unity power factor, the controller is based on an averaged nonlinear state space model of the controlled system. This is carried out via controlling the duty ratio of the DC-DC converter and DC-AC inverter. An integral action was added in order to robustify the controller with respect to parameter variations and disturbances. The synthesis of the regulator wasachieved by having recourse to advanced tools of nonlinearcontrol such as asymptotic stability in the sense of Lyapunov. The performance of the proposed controller is evaluated through numerical simulation in terms of delivering maximum power and synchronization of grid current with grid voltage under changes in atmospheric conditions.
\end{abstract}

Keywords: Grid-connected photovoltaic systems, Maximum power point tracking (MPPT), Unity power factor, Backstepping controller, Asymptotic stability.

\section{Introduction}

Solarenergyhasnonoiseandnopollutionandissustainablewith a series of advantages. It has become one of the mostpotentialgreenenergiesfordevelopment.Photovoltaicrenewableenergy sources has been initiallyused in stand-alone applications, nevertheless, PV systems thatsupply energy directly to the utility grid are becoming more popular because ofthe cost reduction due to the lack of a battery subsystem.Moreover, governmental laws and policies recently created thatfavors grid-connected PV systems have proved to be aneffective way to encourage the use of solarenergy. Photovoltaic grid-connected system needs to use the grid-connectedinverter as power conversion device of the DCoutput of the PV array into AC power.

Grid-connected PV systems still have many technicalproblems to be solved. Firstly, since the output power ofthe solar cell is easily influenced by environmental factorswith obvious nonlinear factor, the photovoltaic cell is a veryunstable power supply, so designing an efficient and reliablemaximum power tracking control strategyis required to match the PV panelpower to the irradiation and temperature changes.Many algorithms have been developed for trackingmaximum point of a PV panel such as Perturb and Observation [1], and Incremental Conductance [2], neural network [3], fuzzy logic control [4] and slidingmode controller [5], [6], [7], [8]. Secondly, since the inverter is running excessive harmoniccurrents injected into the grid, the power system harmonicpollution problem is getting worse. Grid system becomesabnormal and false, and another equipment is also adverselyaffected, so various control strategy is proposed to solve this problem; power controlled [9], current controlled grid connected PV system [10] andhysteresis current control [11].

In this paper, a backsteppingcontrol strategy isdeveloped to track the maximum power of the PV array and to synchronize the grid current with the grid voltage by ensuring the tight regulationof the DC-bus voltageand further reduce the harmonic content of the network current. The concept is to calculate an appropriate controllaw to guarantee the global asymptotic stability of the closedloop system. Thecontrol inputs of the gridconnected PV system are the duty cycles of the DC-DC converter and DC-AC inverter.Thecontrol input of the DC-DC converter achieves the maximum power pointtracking, according to atmospheric condition changes. The control input of the DC-AC inverter achieves the unity power factor with regulationof the DC-link voltage and assure that the output currentpresents both low harmonic distortion and robustnessin front of system's perturbations. 


\section{Grid-Connected PV System Modelling}

The configuration of single-phase grid-connected photovoltaic system is shown in Fig.1. It consists of $\mathrm{PV}$ array connected to the DC bus via a DC-DC boost converter, and then to the AC grid via a DC-AC inverter. The boost converter is used for boosting the array voltage and achieving maximum power point tracking for the PV array. The inverter with filter inductor converts a DC input voltage into an AC sinusoidal, by means of appropriate switch signals to make the output current in phase with the utility voltage and so obtain a power factor unity.

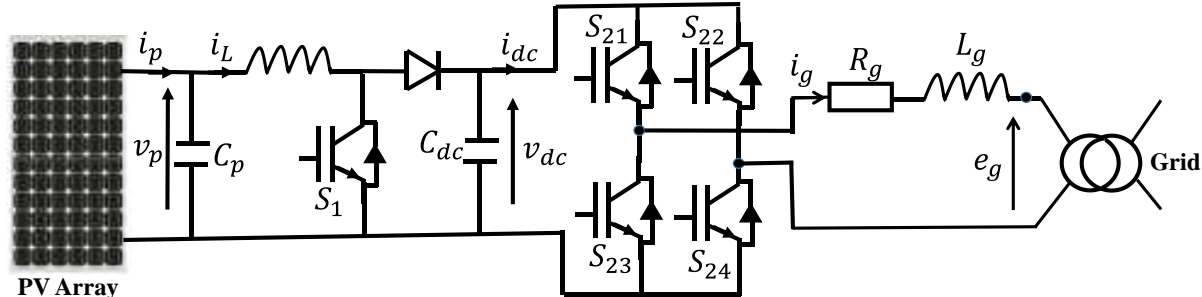

Fig. 1. Single-phase grid connected PV system.

\subsection{Photovoltaic Array Modelling}

Typically, aPVcell isasimple p-n junctiondiode, which converts solar irradiation intoelectricity. Fig. 2 illustrates a simple equivalent circuit diagram of a PV cell.Thismodelconsistsofacurrentsource $\mathrm{I}_{\mathrm{ph}}$ whichrepresentsthelight generated currentfromPVcell,a diode in parallel with the current source, a shunt resistance $R_{\text {sh }}$, and a series resistance $R_{s}$.

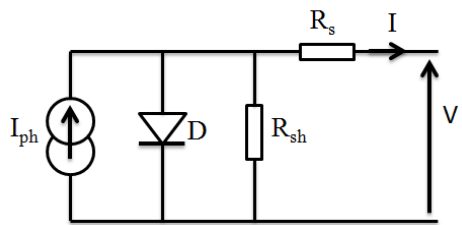

Fig. 2. Equivalent circuit of a PV cell.

The terminal equation for the PV current $i_{p}$ and PV voltage $v_{p}$ of the solar cell is given as follows:

$$
i_{p}=I_{p h}-I_{s}\left[\exp \left(\frac{v_{p}+R_{s} i_{p}}{\gamma V_{T}}\right)-1\right]-\frac{v_{p}+R_{s} i_{p}}{R_{s h}}
$$

where $I_{S}$ is the saturation current, $V_{T}=K_{B} T / q$ is the thermal voltage, $K_{B}$ is the Boltzmann's constant, $\mathrm{q}$ is the charge of electron, $\mathrm{T}$ is the cell's absolute working temperature, $\gamma$ is the $\mathrm{p}-\mathrm{n}$ junction ideality factors. The light generated current $\mathrm{I}_{\mathrm{ph}}$ depends on the solar irradiation and temperature, which can be related by the following equation:

$$
I_{p h}=\left[I_{s c r}+K_{i}\left(T-T_{r}\right)\right] \frac{G}{1000}
$$

where, $I_{s c r}$ is the short circuit current, $G$ is the solar irradiation, $K_{i}$ is the cell's short circuit current coefficient and $\mathrm{T}_{\mathrm{r}}=298.15 \mathrm{~K}$ is the reference temperature of the cell.The cell's saturation current $\mathrm{I}_{\mathrm{s}}$ varies with the temperature according to the following equation:

$$
I_{\mathrm{S}}=\mathrm{I}_{\mathrm{rr}}\left[\frac{\mathrm{T}}{\mathrm{T}_{\mathrm{r}}}\right]^{3}\left[\exp \frac{\mathrm{qE}_{\mathrm{G}}}{\gamma \mathrm{K}_{\mathrm{B}}}\left(\frac{1}{\mathrm{~T}_{\mathrm{r}}}-\frac{1}{\mathrm{~T}}\right)\right]
$$

where, $E_{G}$ is the band-gap energy of the semiconductor used in the cell and $I_{r r}$ is the reverse saturation current of the cell at reference temperature and solar irradiation.

PV cells, usually considered to have the same characteristics, are arranged together in series and parallel to form arrays inordertoobtainahighervoltage andcurrent. The mathematical equation relating the PV array current to the PV array voltage becomes:

$$
\mathrm{i}_{\mathrm{p}}=\mathrm{N}_{\mathrm{p}} \mathrm{I}_{\mathrm{ph}}-\mathrm{N}_{\mathrm{p}} \mathrm{I}_{\mathrm{s}}\left[\exp \frac{1}{\gamma \mathrm{V}_{\mathrm{T}}}\left(\frac{\mathrm{v}_{\mathrm{p}}}{\mathrm{N}_{\mathrm{s}}}+\frac{\mathrm{R}_{\mathrm{s}} \mathrm{i}_{\mathrm{p}}}{\mathrm{N}_{\mathrm{p}}}\right)-1\right]-\frac{\mathrm{N}_{\mathrm{p}}}{\mathrm{R}_{\mathrm{sh}}}\left(\frac{\mathrm{v}_{\mathrm{p}}}{\mathrm{N}_{\mathrm{s}}}+\frac{\mathrm{R}_{\mathrm{s}} \mathrm{i}_{\mathrm{p}}}{\mathrm{N}_{\mathrm{p}}}\right)
$$

where $N_{s}$ is the number of cells in series and $N_{p}$ is the number of modules in parallel.

The PV array considered in this paper is the Siemens SM55. The corresponding electrical characteristics are listed in Table 1.

\begin{tabular}{|c|c|}
\hline Nominal voltage & $12 \mathrm{~V}$ \\
\hline Maximum power & $55 \mathrm{~W}$ \\
\hline Current at the maximum power point & $3.15 \mathrm{~A}$ \\
\hline Voltage at the maximum power point & $17.4 \mathrm{~V}$ \\
\hline
\end{tabular}




\begin{tabular}{|c|c|}
\hline Maximum current (short circuit output) & $3.45 \mathrm{~A}$ \\
\hline Maximum voltage (open circuit) & $21.7 \mathrm{~V}$ \\
\hline Current temperature coefficient & $+1.2 \mathrm{~mA} /{ }^{\circ} \mathrm{C}$ \\
\hline Number of series cells $\mathrm{N}_{\mathrm{s}}$ & 36 \\
\hline Number of parallel modules $\mathrm{N}_{\mathrm{p}}$ & 1 \\
\hline
\end{tabular}

Table 1: Parameter values of the PV array Siemens SM55.

Figs. 3 and 4 show the constitutive curves of the PV array for different values of temperature and solar incident irradiance. Two important electricalcharacteristics of the PV array are observed in those figures:That there is an operating point, marked in the figures, in which the PV array generates more power than the other points. That there are different maximum power points for each curve. The aforementioned observations imply that during one day the maximum powerpoint of a PV array varies according to the solar incident irradiance and temperaturechanges.
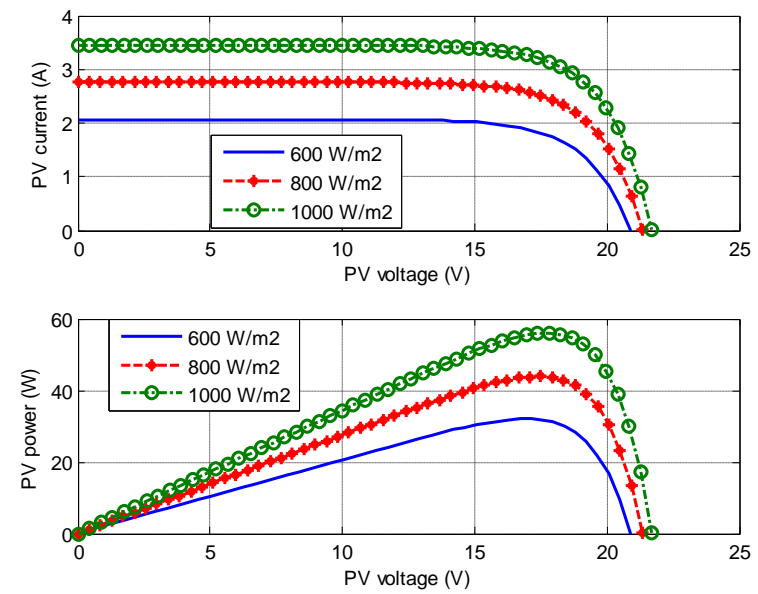

Fig. 3. $\mathrm{PV}$ array current-voltage and $\mathrm{PV}$ array power-voltage at $25^{\circ} \mathrm{C}$ at different irradiance levels.
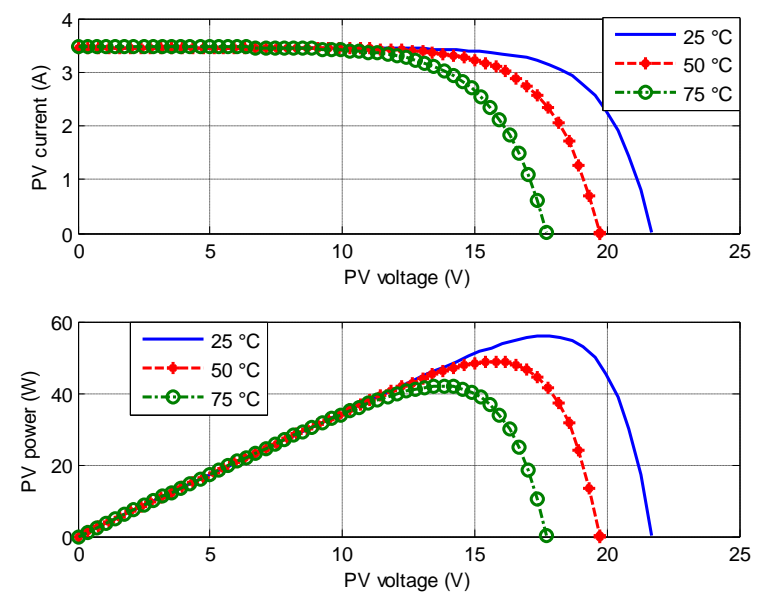

Fig. 4. PV array current-voltage and PV array power-voltage at $1000 \mathrm{~W} / \mathrm{m}^{2}$ at different temperature levels.

Based on the solar array characteristic curves shown in Figs. 3 and 4, it can be found that a maximum power point occurs when the derivative of $P V$ output powerP $=v_{p} i_{p}$ with respect to terminal voltagev $v_{p}$ equals zero. Therefore:

$$
\left.\frac{\partial \mathrm{P}}{\partial \mathrm{v}_{\mathrm{p}}}\right|_{\mathrm{MPP}}=\frac{\partial\left(\mathrm{v}_{\mathrm{p}} \mathrm{i}_{\mathrm{p}}\right)}{\partial \mathrm{v}_{\mathrm{p}}}=\mathrm{i}_{\mathrm{p}}+\mathrm{v}_{\mathrm{p}} \frac{\partial \mathrm{i}_{\mathrm{p}}}{\partial \mathrm{v}_{\mathrm{p}}}=0
$$

\subsection{Single-phase Grid-connected PV System Modelling}

Thepower converter structure used tointerface the photovoltaic array with the power gridas shown in Fig 2.In the specific architecture consideredin this work, the PV panel is connected to the inputof a single fullbridge power inverter by means of a DC-DC converter and a DC-link capacitor. The DC-DC boost converter consists of the switch $S_{1}$ controlled by a switching signal $\mu_{1} \in\{0,1\}$ (i.e., OFF or ON respectively) and the fullbridge inverter consists of four switches $\left\{\mathrm{S}_{21}, \mathrm{~S}_{22}, \mathrm{~S}_{23}, \mathrm{~S}_{24}\right\}$ controlled bya switching signal $\mu_{2} \in\{0,1\}$. The 
switching signal $\mu_{1}$ and $\mu_{2}$ can also be generated via a pulse-width modulator (PWM)scheme with an input signal $\mathrm{u}_{\mathrm{i}}(\mathrm{i}=1,2) \in[0,1]$ outputted by the controller. In this case, if theswitching frequency is sufficiently high, the dynamical behavior of the PV system canbe approximated by the following set of differential equations:

$$
\left\{\begin{array}{c}
\frac{d v_{p}}{d t}=\frac{1}{C_{p}} i_{p}-\frac{1}{C_{p}} i_{L} \\
\frac{d i_{L}}{d t}=\frac{1}{L} v_{p}-\frac{1}{L}\left(1-u_{1}\right) v_{d c} \\
\frac{d v_{d c}}{d t}=\frac{1}{C_{d c}}\left(1-u_{1}\right) i_{L}+\frac{1}{C_{c d}}\left(1-2 u_{2}\right) i_{g} \\
\frac{d i_{g}}{d t}=-\frac{1}{L_{g}} R_{g} i_{g}-\frac{1}{L_{g}} e_{g}-\frac{1}{L_{g}}\left(1-2 u_{2}\right) v_{d c} \\
y_{1}=\frac{\partial P}{\partial v_{p}}=i_{p}+v_{p} \frac{\partial i_{p}}{\partial v_{p}} \\
y_{2}=i_{g}
\end{array}\right.
$$

where $\mathrm{C}_{\mathrm{p}}$ is the input capacitor and $\mathrm{L}$ is the inductor of the boost converter. $\mathrm{C}_{\mathrm{dc}}$ is the DC link capacitor, $\mathrm{L}_{\mathrm{g}}$ is the filter inductor and $\mathrm{R}_{\mathrm{g}}$ is the equivalent series resistance of the filter inductor. $\mathrm{i}_{\mathrm{p}}, \mathrm{v}_{\mathrm{p}}, \mathrm{i}_{\mathrm{L}}, \mathrm{v}_{\mathrm{dc}}, \mathrm{i}_{\mathrm{g}}$ and $\mathrm{e}_{\mathrm{g}}$ are respectively, the average values over switching period of the PV array current, $\mathrm{PV}$ array voltage, boost inductor current, DC bus voltage, grid current and grid voltage, $\mathrm{y}_{1}$ and $\mathrm{y}_{2}$ are the controlled outputs of the power system. The control inputs $\mathrm{u}_{1}$ and $\mathrm{u}_{2}$ are the average values (duty cycles) of the binary input switching signals $\mu_{1}$ and $\mu_{2}$. The utility grid voltage $e_{\mathrm{g}}=\mathrm{A} \sin (\omega \mathrm{t})$ is assumed to be sinusoidal with a constant amplitudeAand a constant frequency $\omega=2 \pi \mathrm{f}$.

\section{Controller Design}

The control strategy of the power converter and power inverter that interface the PV array with theutility grid needs to accomplish the following control objectives in order to assure anefficient energy transfer:

- The maximum power extraction from the PV array by means of tracking the solar array maximum power point (MPP) that varies with the solar irradiance and the PV array temperature.

- The proper conversion of the DC input power into an AC output current, which has to be injected to the grid. This current has to exhibit low harmonic contents and must be in phase to the grid voltage in order to perform the power transfer at unity power factor.

- The tight regulation of the DC-bus voltage.

To accomplish the previous objectives, a nonlinear controller is developed using the backstepping technique based on the averaged nonlinear state space model of the controlled system. The proposed control system will have the structure shown in Fig.5. The MPPT controller and unity power factor controller will be synthesized using backstepping approach [12], [13], [14], [15] and the third will bedone by a simple proportional-integral corrector.

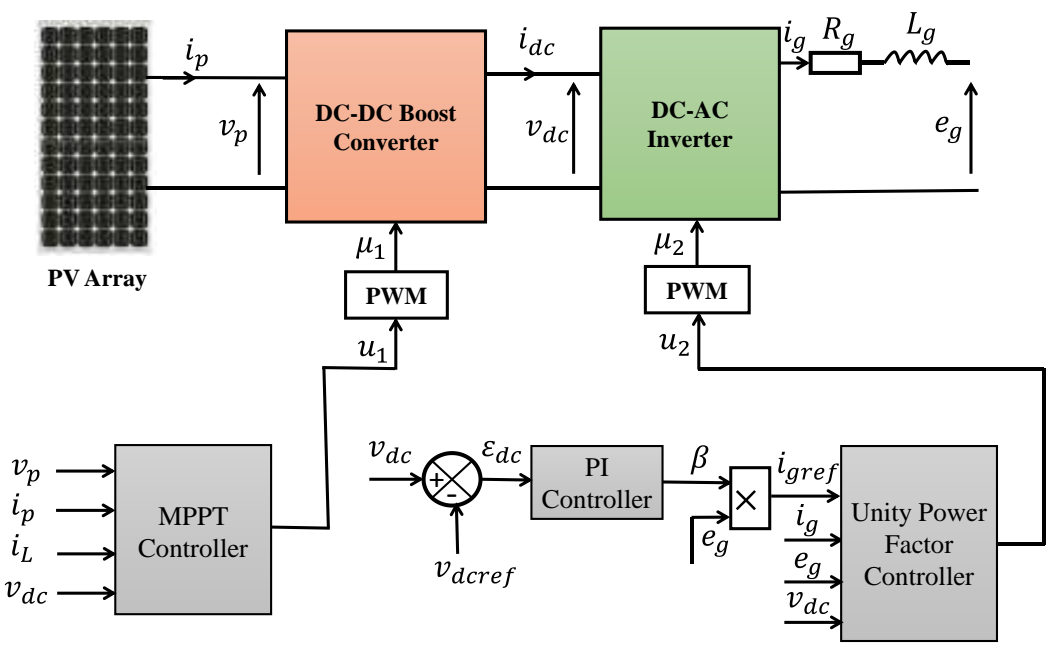

Fig. 5.Control scheme of the grid-connected PV system.

\subsection{MPPT Controller}

The maximum power point tracking controlhas to settle the PV array operating pointat itsmaximumpower valuefor anytemperatureandirradiance variation, bymeansof the input signal $\mathrm{u}_{1}$ that controls 
the switch of the boost converter. The control objective is to regulate the controlled output $\mathrm{y}_{1}=\frac{\partial \mathrm{P}}{\partial \mathrm{v}_{\mathrm{p}}}$ of the photovoltaic array to its reference $\mathrm{y}_{1 \mathrm{ref}}=\left.\frac{\partial \mathrm{P}}{\partial \mathrm{v}_{\mathrm{p}}}\right|_{\mathrm{MPP}}=0$.

Backstepping design procedure:

Design Step:Let us introduce the following tracking error $\varepsilon_{1}=y_{1}-y_{1 \text { ref }}$ and including integral action $\xi_{1}(t)=$ $\int_{0}^{t}\left(\mathrm{y}_{1}(\tau)-\mathrm{y}_{1 \mathrm{ref}}(\tau)\right) \mathrm{d} \tau$.

Deriving $\varepsilon_{1}$ with respect to time and accounting for (5) and (6), implies:

$$
\dot{\varepsilon}_{1}=\frac{1}{C_{\mathrm{p}}}\left(2 \frac{\partial \mathrm{i}_{\mathrm{p}}}{\partial \mathrm{v}_{\mathrm{p}}}+\mathrm{v}_{\mathrm{p}} \frac{\partial^{2} \mathrm{i}_{\mathrm{p}}}{\partial \mathrm{v}_{\mathrm{p}}{ }^{2}}\right)\left(\mathrm{i}_{\mathrm{p}}-\mathrm{i}_{\mathrm{L}}\right)
$$

Treating the boost inductor current $\mathrm{i}_{\mathrm{L}}$ as a virtual control signal for (7) and considering the first Lyapunov function positive definite:

$$
\mathrm{V}_{1}\left(\xi_{1}, \varepsilon_{1}\right)=\frac{1}{2} \xi_{1}{ }^{2}+\frac{1}{2} \varepsilon_{1}^{2}
$$

The derivative of $\mathrm{V}_{1}$ with respect to time, is given by:

$$
\dot{\mathrm{V}}_{1}=\varepsilon_{1}\left[\xi_{1}+\frac{1}{C_{\mathrm{p}}}\left(2 \frac{\partial \mathrm{i}_{\mathrm{p}}}{\partial \mathrm{v}_{\mathrm{p}}}+\mathrm{v}_{\mathrm{p}} \frac{\partial^{2} \mathrm{i}_{\mathrm{p}}}{\partial \mathrm{v}_{\mathrm{p}}^{2}}\right)\left(\mathrm{i}_{\mathrm{p}}-\mathrm{i}_{\mathrm{L}}\right)\right]
$$

As $i_{L}$ is just a state variable and not an effective controlinput, the stabilization of $\xi_{1}$ and $\varepsilon_{1}$ can be obtained by introducing a new virtual control $\alpha_{1}=\left(\mathrm{i}_{\mathrm{L}}\right)_{\mathrm{d}}$, where $\left(\mathrm{i}_{\mathrm{L}}\right)_{\mathrm{d}}$ is the desired value of the boost inductor current. The virtual control law would be:

$$
\xi_{1}+\frac{1}{C_{p}}\left(2 \frac{\partial \mathrm{i}_{\mathrm{p}}}{\partial \mathrm{v}_{\mathrm{p}}}+\mathrm{v}_{\mathrm{p}} \frac{\partial^{2} \mathrm{i}_{\mathrm{p}}}{\partial \mathrm{v}_{\mathrm{p}}^{2}}\right)\left(\mathrm{i}_{\mathrm{p}}-\alpha_{1}\right)=-\mathrm{k}_{1} \varepsilon_{1}
$$

Wherek $k_{1}>0$ being a design parameter. Thedesired value $\alpha_{1}$ is called a stabilization function, is given by:

$$
\alpha_{1}=\mathrm{i}_{\mathrm{p}}+\frac{\mathrm{C}_{\mathrm{p}}}{2 \frac{\partial \mathrm{i}}{\partial \mathrm{v}_{\mathrm{p}}}+\mathrm{v}_{\mathrm{p}} \frac{\partial^{2} \mathrm{p}}{\partial \mathrm{v}_{\mathrm{p}}^{2}}}\left(\mathrm{k}_{1} \varepsilon_{1}+\xi_{1}\right)
$$

The Lyapunov candidate function whose dynamics is negative definite: $\dot{V}_{1}=-\mathrm{k}_{1} \varepsilon_{1}^{2}<0$.

Design Step 2: We define the following second error variable of the boost inductor current error $\varepsilon_{2}=\mathrm{i}_{\mathrm{L}}-\alpha_{1}$, where the inductor current should reach the desired value $\alpha_{1}$ to make the error vanish in order to achieve the control aim. The time derivative of this error is:

$$
\dot{\varepsilon}_{2}=\frac{\mathrm{di}_{\mathrm{L}}}{\mathrm{dt}}-\dot{\alpha}_{1}=\frac{1}{\mathrm{~L}}\left(\mathrm{v}_{\mathrm{p}}-\left(1-\mathrm{u}_{1}\right) \mathrm{v}_{\mathrm{dc}}\right)-\dot{\alpha}_{1}
$$

Substituting $\mathrm{i}_{\mathrm{L}}=\varepsilon_{2}+\alpha_{1}$ into equation (7), $\dot{\varepsilon}_{1}$ becomes:

$$
\dot{\varepsilon}_{1}=\frac{1}{C_{p}}\left(2 \frac{\partial \mathrm{i}_{p}}{\partial v_{p}}+v_{p} \frac{\partial^{2} i_{p}}{\partial v_{p}{ }^{2}}\right)\left(i_{p}-\varepsilon_{2}-\alpha_{1}\right)
$$

Introducing (11), we obtain the time derivative of $\varepsilon_{1}$ and $\mathrm{V}_{1}$ :

$$
\begin{aligned}
& \dot{\varepsilon}_{1}=-\mathrm{k}_{1} \varepsilon_{1}-\xi_{1}-\frac{1}{\mathrm{C}_{\mathrm{p}}}\left(2 \frac{\partial \mathrm{i}_{\mathrm{p}}}{\partial \mathrm{v}_{\mathrm{p}}}+\mathrm{v}_{\mathrm{p}} \frac{\partial^{2} \mathrm{i}_{\mathrm{p}}}{\partial \mathrm{v}_{\mathrm{p}}^{2}}\right) \varepsilon_{2} \\
& \dot{\mathrm{V}}_{1}=-\mathrm{k}_{1} \varepsilon_{1}{ }^{2}-\frac{1}{\mathrm{C}_{\mathrm{p}}}\left(2 \frac{\partial \mathrm{i}_{\mathrm{p}}}{\partial \mathrm{v}_{\mathrm{p}}}+\mathrm{v}_{\mathrm{p}} \frac{\partial^{2} \mathrm{i}_{\mathrm{p}}}{\partial \mathrm{v}_{\mathrm{p}}}\right) \varepsilon_{1} \varepsilon_{2}
\end{aligned}
$$

Thetime derivative of the stabilising function $\alpha_{1}$ is given by:

$$
\dot{\alpha}_{1}=\left[\frac{\partial \mathrm{i}_{\mathrm{p}}}{\partial \mathrm{v}_{\mathrm{p}}} \frac{\partial \mathrm{v}_{\mathrm{p}}}{\partial \mathrm{t}}+\mathrm{C}_{\mathrm{p}}\left(\frac{\left(\mathrm{k}_{1} \dot{\varepsilon}_{1}+\varepsilon_{1}\right)}{\left(2 \frac{\partial \mathrm{i}_{\mathrm{p}}}{\partial \mathrm{v}_{\mathrm{p}}}+\mathrm{v}_{\mathrm{p}} \frac{\partial^{2} \mathrm{i}_{\mathrm{p}}}{\partial \mathrm{v}_{\mathrm{p}}}\right)}-\frac{\left(\mathrm{k}_{1} \varepsilon_{1}+\xi_{1}\right)}{\left(2 \frac{\partial \mathrm{i}_{\mathrm{p}}}{\partial \mathrm{v}_{\mathrm{p}}}+\mathrm{v}_{\mathrm{p}} \frac{\partial \mathrm{z}_{\mathrm{p}}}{\left.\partial \mathrm{v}_{\mathrm{p}}\right)^{2}}\right)^{2}}\left(3 \frac{\partial^{2} \mathrm{i}_{\mathrm{p}}}{\partial \mathrm{v}_{\mathrm{p}}{ }^{2}}+\mathrm{v}_{\mathrm{p}} \frac{\partial^{3} \mathrm{i}_{\mathrm{p}}}{\partial \mathrm{v}_{\mathrm{p}}}{ }^{3}\right) \frac{\partial \mathrm{v}_{\mathrm{p}}}{\partial \mathrm{t}}\right)\right]
$$

Consider the augmented Lyapunov functioncandidate:

$$
\mathrm{V}_{2}\left(\xi_{1}, \varepsilon_{1}, \varepsilon_{2}\right)=\mathrm{V}_{1}+\frac{1}{2} \varepsilon_{2}^{2}
$$

The time derivative of the second Lyapunov function is obtained by combining equations (12) and (15):

$$
\dot{\mathrm{V}}_{2}=-\mathrm{k}_{1} \varepsilon_{1}{ }^{2}+\varepsilon_{2}\left[-\frac{1}{C_{\mathrm{p}}}\left(2 \frac{\partial \mathrm{i}_{\mathrm{p}}}{\partial \mathrm{v}_{\mathrm{p}}}+\mathrm{v}_{\mathrm{p}} \frac{\partial^{2} \mathrm{i}_{\mathrm{p}}}{\partial \mathrm{v}_{\mathrm{p}}{ }^{2}}\right) \varepsilon_{1}+\frac{1}{\mathrm{~L}}\left(\mathrm{v}_{\mathrm{p}}-\mathrm{v}_{\mathrm{dc}}\right)+\frac{1}{\mathrm{~L}} \mathrm{u}_{1} \mathrm{v}_{\mathrm{dc}}-\dot{\alpha}_{1}\right]
$$

The control law $\mathrm{u}_{1}$ which guaranteesthe negativity of the dynamics of the Lyapunov candidatefunction $V_{2}$, is given by:

$$
\mathrm{u}_{1}=\frac{\mathrm{L}}{\mathrm{v}_{\mathrm{dc}}}\left[-\mathrm{k}_{2} \varepsilon_{2}+\frac{1}{\mathrm{C}_{\mathrm{p}}}\left(2 \frac{\partial \mathrm{i}_{\mathrm{p}}}{\partial \mathrm{v}_{\mathrm{p}}}+\mathrm{v}_{\mathrm{p}} \frac{\partial^{2} \mathrm{i}_{\mathrm{p}}}{\partial \mathrm{v}_{\mathrm{p}}^{2}}\right) \varepsilon_{1}-\frac{1}{\mathrm{~L}}\left(\mathrm{v}_{\mathrm{p}}-\mathrm{v}_{\mathrm{dc}}\right)+\dot{\alpha}_{1}\right]
$$

where $\mathrm{k}_{2}>0$ is a positive constant. The above choice yields:

$$
\dot{\mathrm{V}}_{2}=-\mathrm{k}_{1} \varepsilon_{1}^{2}-\mathrm{k}_{2} \varepsilon_{2}^{2}<0
$$

which ensures that the state vector error $\left(\xi_{1}, \varepsilon_{1}, \varepsilon_{2}\right)$ converges asymptotically to the origin, which implies that $\varepsilon_{1}=\mathrm{y}_{1}-\mathrm{y}_{1 \mathrm{ref}}=\partial \mathrm{P} / \partial \mathrm{v}_{\mathrm{p}}$ converges asymptotically to the origin, Therefore, the maximum power extraction from the PV array is achieved. 


\subsection{Unity Power Factor Controller}

The unity power factor controller input signal $\mathrm{u}_{2}$ that controls the inverterhave been carried out by means of on two cascaded control loops, where theinner current control loop is in charge to establish the duty ratio for the generation ofa sinusoidal output current in phase with the grid voltage and ensuring current harmonics rejection. In turn, the outer voltagecontrol loop has to settle the DC bus voltage regulating at its desired value,this loop delivers to the inner control loop the currentreference amplitude corresponding to the PV array maximum power, thereby ensuringthe power transfer to the grid.

The inner controllerallows the grid current $i_{g}$ to track a reference signal $i_{\text {gref }}$ of the form:

$$
i_{\text {gref }}=\beta \mathrm{e}_{\mathrm{g}}=\beta A \sin (\omega \mathrm{t})
$$

Where $\beta$ isanadjustmentpositive parameter anditcanbeadjustedbyaPIcontrol.

Let us introduce thefollowing tracking current error $\varepsilon_{3}=\mathrm{y}_{2}-\mathrm{y}_{2 \mathrm{ref}}=\mathrm{i}_{\mathrm{g}}-\mathrm{i}_{\text {gref }}$. Itsdynamics is given by:

$$
\dot{\varepsilon}_{3}=-\frac{1}{\mathrm{Lg}_{\mathrm{g}}} \mathrm{R}_{\mathrm{g}} \mathrm{i}_{\mathrm{g}}-\frac{1}{\mathrm{Lg}_{\mathrm{g}}} \mathrm{e}_{\mathrm{g}}-\frac{1}{\mathrm{Lg}_{\mathrm{g}}}\left(1-2 \mathrm{u}_{2}\right) \mathrm{v}_{\mathrm{dc}}-\frac{\mathrm{di} \mathrm{gref}}{\mathrm{dt}}
$$

Let us use the Lyapunov candidate function by introducing the integral action $\xi_{2}(t)=\int_{0}^{t}\left(i_{g}(\tau)-i_{\text {gref }}(\tau)\right) d \tau$ :

$$
\mathrm{V}_{3}\left(\xi_{2}, \varepsilon_{3}\right)=\frac{1}{2} \xi_{2}^{2}+\frac{1}{2} \varepsilon_{3}^{2}
$$

As its derivative with respect to time, is given by:

$$
\dot{\mathrm{V}}_{3}=\varepsilon_{3}\left[\xi_{2}-\frac{1}{\mathrm{Lg}_{\mathrm{g}}} \mathrm{R}_{\mathrm{g}} \mathrm{i}_{\mathrm{g}}-\frac{1}{\mathrm{Lg}_{\mathrm{g}}} \mathrm{e}_{\mathrm{g}}-\frac{1}{\mathrm{Lg}_{\mathrm{g}}}\left(1-2 \mathrm{u}_{2}\right) \mathrm{v}_{\mathrm{dc}}-\frac{\mathrm{di} \text { gref }}{\mathrm{dt}}\right]
$$

The stabilizing control law by making $\dot{V}_{3}$ negative definite is given by:

$$
\mathrm{u}_{2}=\frac{1}{2}\left[1+\frac{1}{\mathrm{v}_{\mathrm{dc}}}\left(\mathrm{R}_{\mathrm{g}} \mathrm{i}_{\mathrm{g}}+\mathrm{e}_{\mathrm{g}}+\mathrm{L}_{\mathrm{g}}\left(\frac{\mathrm{di}_{\mathrm{gref}}}{\mathrm{dt}}-\mathrm{k}_{3} \varepsilon_{3}-\xi_{2}\right)\right)\right]
$$

wherek $k_{3}>0$ is a positive parameter; which yields $\dot{V}_{3}=-\mathrm{k}_{3} \varepsilon_{3}{ }^{2}<0$, then the tracking error $\varepsilon_{3}$ converges asymptotically to zero.Therefore, thegrid current is sinusoidal and in phase with the grid voltage.

The aim of the outer voltage loopis to design a variation law for the ratio ßin equation (21) sothat the inverter DC input voltage $\mathrm{v}_{\mathrm{dc}}$ issteered to a given constant reference $\mathrm{d}_{\mathrm{dcref}}$. This regulatorisgiven by the following PI controllaw:

$$
\beta(t)=k_{4}\left(v_{d c}(t)-v_{\text {dcref }}(t)\right)+k_{5} \int_{0}^{t}\left(v_{d c}(\tau)-v_{\text {dcref }}(\tau)\right) d \tau(26)
$$

where $\mathrm{k}_{4}$ and $\mathrm{k}_{5}$ are respectively the proportional and integral gain.

\section{Simulation Results and Discussions}

Numerical simulations were made in the Simulink/Matlabplatform to verify the performance of thecontroller;all parameters of thephotovoltaic system componentsand controller are depicted in Table 2.Two scenarios were simulated. In the first one,realistic variations were applied to the irradiance from $500 \mathrm{~W} / \mathrm{m}^{2}$ to $1000 \mathrm{~W} / \mathrm{m}^{2}$ at 0.5 swhile maintainingthe cell temperature constant at $25^{\circ} \mathrm{C}$. Theresulting control performances are illustrated by Fig. 6 to Fig. 9. The reference DC bus voltage valueis held atv $\mathrm{dcref}=40 \mathrm{~V}$. Thesecondscenario was simulated for temperature changes from $25^{\circ} \mathrm{C}$ to $50^{\circ} \mathrm{C}$ at $0.5 \mathrm{~s}$ while the radiation is constant equal to $1000 \mathrm{~W} / \mathrm{m}^{2}$.The corresponding performances are illustrated by Fig. 10 to Fig. 13.

From these Figures, it is clear that the maximum power point is always reached very quickly with excellent accuracy and good performances according to atmospheric condition changes. The grid current is sinusoidal and in phase with the grid voltage, which proves the unity power factor achievement. Noting that the DC bus voltage is regulated to its desired value.In addition to that,this controller has tobe used in orderto achieve the synchronization tothe grid and to perform the power managementbetween the PV system and the electrical grid.

\begin{tabular}{|l|l|l|}
\hline \multicolumn{1}{|c|}{$\begin{array}{c}\text { Photovoltaic array } \\
\text { parameters }\end{array}$} & \multicolumn{1}{c|}{$\begin{array}{c}\text { Boost converter, inverter and grid } \\
\text { parameters }\end{array}$} & \multicolumn{1}{c|}{$\begin{array}{c}\text { Controller } \\
\text { parameters }\end{array}$} \\
\hline $\mathrm{R}_{\mathrm{s}}=0.1124 \Omega$ & $\mathrm{C}_{\mathrm{p}}=4700 \mu \mathrm{F}$ & $\mathrm{k}_{1}=900$ \\
\hline $\mathrm{R}_{\mathrm{sh}}=6500 \Omega$ & $\mathrm{C}_{\mathrm{dc}}=470 \mu \mathrm{F}$ & $\mathrm{k}_{2}=900$ \\
\hline$\gamma=1.7404$ & $\mathrm{~L}=3.5 \mathrm{mH}$ & $\mathrm{k}_{3}=200$ \\
\hline $\mathrm{I}_{\mathrm{scr}}=3.45 \mathrm{~A}$ & $\mathrm{~L}_{\mathrm{g}}=2.2 \mathrm{mH}$ & $\mathrm{k}_{4}=0.01$ \\
\hline $\mathrm{I}_{\mathrm{rr}}=4.842 \mu \mathrm{A}$ & $\mathrm{R}_{\mathrm{g}}=0.7 \Omega$ & $\mathrm{k}_{5}=1$ \\
\hline $\mathrm{N}_{\mathrm{s}}=36$ & $\mathrm{~A}=22 \sqrt{2} \mathrm{~V} ; \mathrm{f}=50 \mathrm{~Hz}$ & \\
\hline $\mathrm{N}_{\mathrm{p}}=1$ & $\mathrm{v}_{\mathrm{dcref}}=40 \mathrm{~V}$ & \\
\hline
\end{tabular}

Table 2: Power system and controller parameters. 

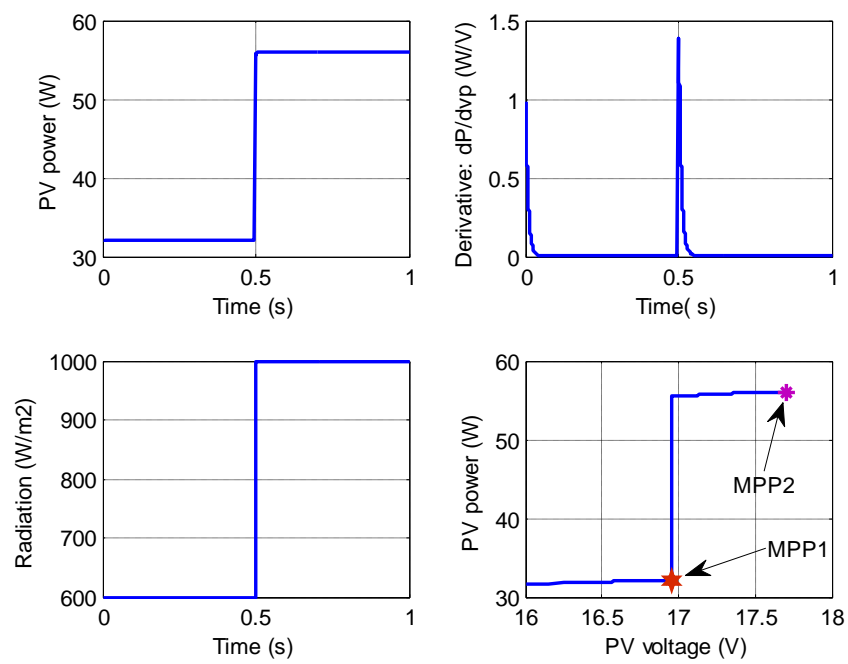

Fig. 6. PV power, controlled output, radiation and PV array power-voltage characteristic in presence of radiation changes.
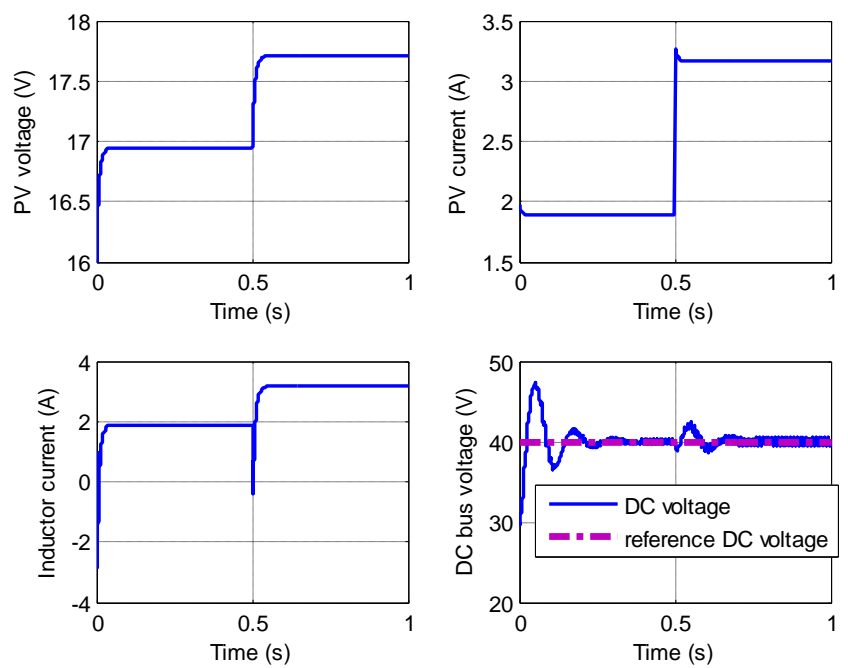

Fig. 7. PV array voltage, $\mathrm{PV}$ array current, boost inductor current and DC bus voltage in presence of radiation changes.
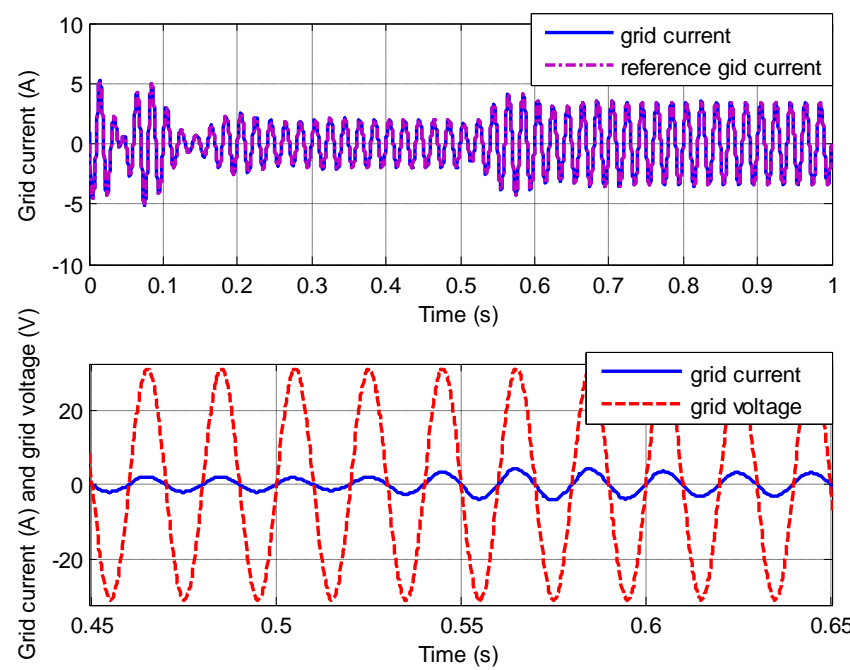

Fig. 8. Grid current and its reference and grid voltage in presence of radiation changes. 

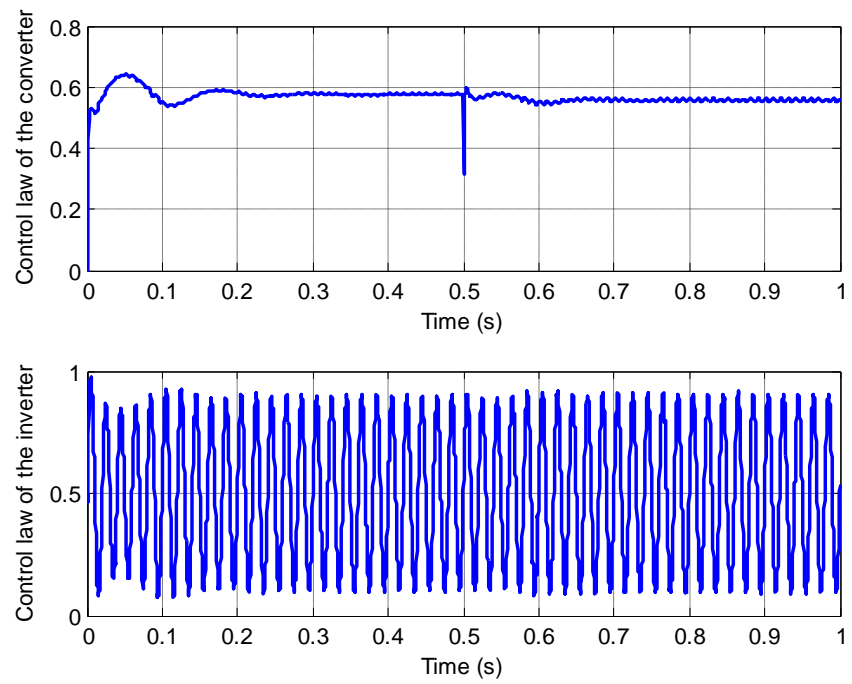

Fig. 9. Input controls of the converter and inverter in presence of radiation changes.
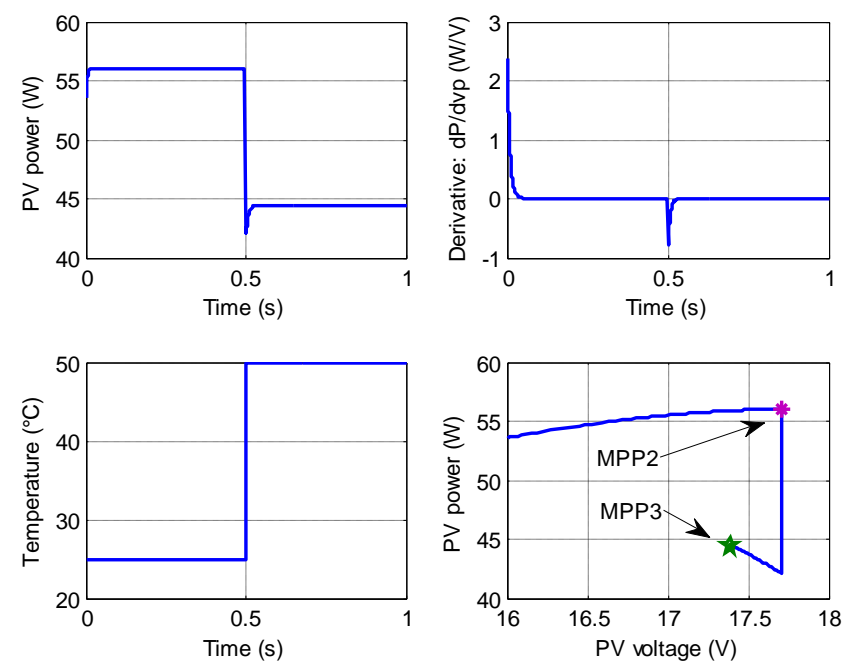

Fig. 10. PV power, controlled output, temperature and PV array power-voltage characteristic in presence of temperature changes.
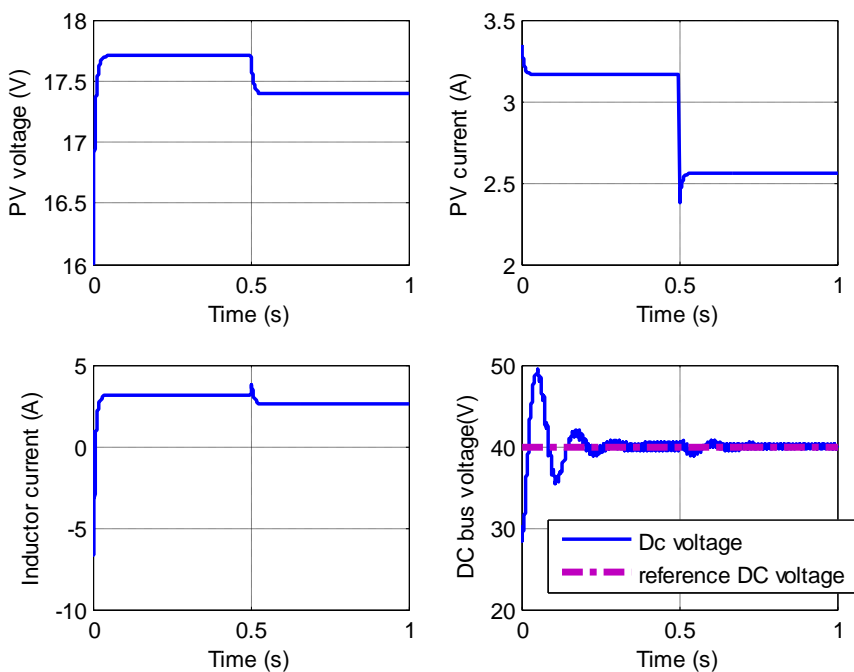

Fig. 11. $P V$ array voltage, $P V$ array current, boost inductor current and $D C$ bus voltage in presence of temperature changes. 

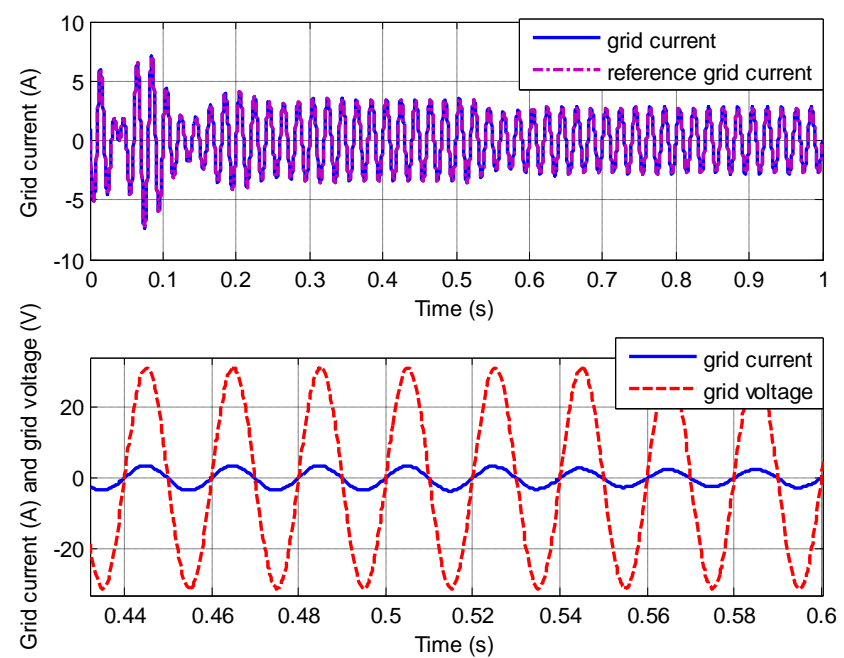

Fig. 12. Grid current and its reference and grid voltage in presence of temperature changes.
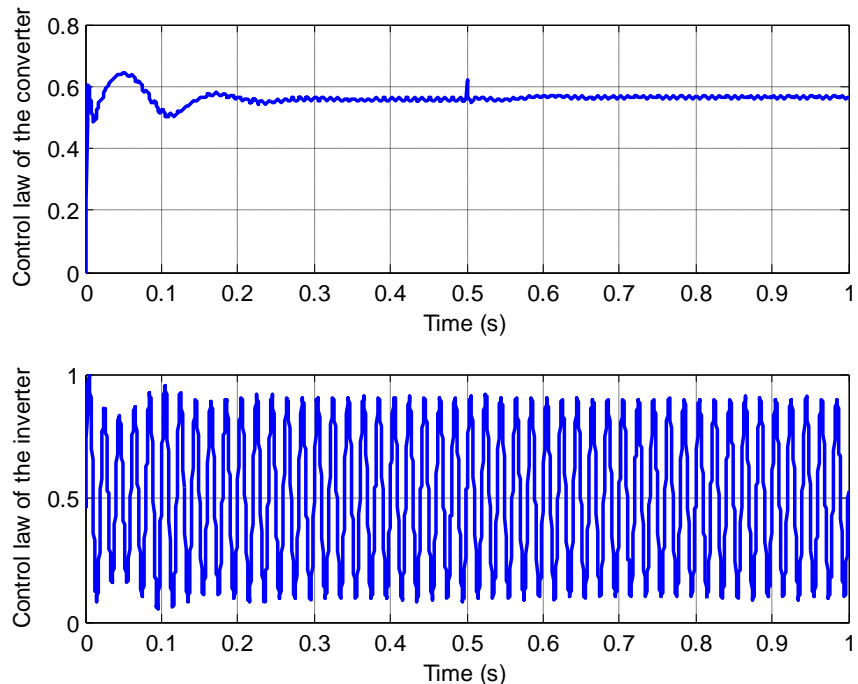

Fig. 13. Input controls of the converter and inverter in presence of temperature changes.

\section{Conclusion}

This paper presents a new nonlinear control strategy of single-phase grid-connected PV generation system. The controller is designed to extract maximum power from the PV array and to inject a sinusoidal current in the grid with unity power factor and regulating the DC bus voltage. The studied system is described by a representation of nonlinear state space average model. To track the designed trajectory, a tow backstepping controller and a proportional-integral corrector are developed to modulate the duty cycle of the interleaved boost converter and inverter. The controller is proven to yield asymptotic stability with respect to the tracking errors via Lyapunov analysis. The proposed controller has the advantages of robustness, accurate tracking, fast response and good performance. Simulationresults, obtained under Matlab/Simulink environment, show the controlperformance and dynamic behavior of grid-connected photovoltaic system providesgood results and show that the control system is robust and efficiency.

\section{References}

[1] N. Femia, G. Petrone, G. Spagnuolo, and M. Vitelli, Optimization of Perturb and Observe maximum power point tracking method, Power Electronics, IEEE Transactions, Vol. 20, n.4, July 2005, pp. 963-973.

[2] Jae Ho Lee; HyunSuBae; Bo Hyung Cho, Advanced Incremental Conductance MPPT Algorithm with a Variable Step Size, Power Electronics and Motion Control Conference EPEPEMC 12th International, Sept 2006, pp. 603 - 607.

[3] A. Tariq and M. S. Jami Asghar, Development of an Analog Maximum Power Point Tracker for Photovoltaic Panel,International IEEE Annual Conference on Power and Electronics and Drives Systems, Vol.1, Jan. 2006, pp.251-255.

[4] NoppornPatcharaprakiti, SuttichaiPremrudeepreechacharn, YosanaiSriuthaisiriwong, Maximum power point tracking using adaptive fuzzy logic control for grid-connected photovoltaic system, Renewable Energy, Vol 30 n.11, Sept 2005, pp. 1771-1778. 
[5] HazemFeshara, Mohamed Elharony, SolimanSharaf, Design, Digital Control, and Simulation of a GridConnected Photovoltaic Generation System. International Journal of Renewable Energy Research, Vol.4, No.2, 2014.

[6] Jui-Liang, Ding-Tsair Su, Ying-ShingShiao, Research on MPPT and Single-Stage Grid-Connected for Photovoltaic System, Wseas Transactions on Systems, Volume 7, October 2008

[7] M. Guisser, A. EL-Jouni, EL. H. Abdelmounim, Robust Sliding Mode MPPT Controller Based on High Gain Observer of a Photovoltaic Water Pumping System, International Review of Automatic Control, Vol 7, No 2, 2014.

[8] M'hammedGuisser, ElhassaneAbdelmounim, Mohammed Aboulfatah, Abdesselam EL-Jouni, Nonlinear Observer-Based Control for Grid Connected Photovoltaic System, IOSR Journal of Electrical and Electronics Engineering, Volume 9, 2014.

[9] F. L. Albuquerque, A. J. Moraes, G. C. Guimarks, S. M. R. Sanhueza, optimization of a photovoltaic system connected to electric power grid, IEEE transaction and distribution conference and exposition, pp. 645-650. Latin Americain, 2004.

[10] Jianxing Liu, Salah Laghrouche, MaximeWack, Observer-Based Higher Order Sliding Mode Control of Unity Power Factor in Three-Phase AC/DC Converter for Hybrid Electric Vehicle Applications, International Journal of Control, 2013.

[11] G. He-rong, Y. Zi-long, W. Wu, Research on hysteresis band current tracking control of grid-connected inverter, Proceedings of the Chinese Society of Electrical Engineering,vol. 26,no.9,pp.108-112,2006.

[12] Krstić M., I. Kanellakopoulos, P. V. Kokotović. Nonlinear and adaptive control design. John Willy \& Sons, NY, 1995.

[13] Y. Tan, J. Chang, H. Tan, and J. Hu, Integral backstepping control and experimental implementation for motion system, in Proc. IEEE Int. Conf. Contr. Appl., (Anchorage, Alaska, USA), pp. 367-372, IEEE, Sept. 2000.

[14] Roger Skjetne, Thor I. Fossen, On Integral Control in Backstepping: Analysis of Different Techniques, Proceeding of the American Control Conference Boston, Massachusetts June 30-July 2, 2004.

[15] Chao-Chung Peng, Yunze Li and Chieh-Li Chen, A Robust Integral Type Backstepping Controller Design for Control of Uncertain Non Linear Systems subject to Disturbance, International Journal of Innovative Computing, Information and Control, Volume7, Number 5(A), May 2011. 